\title{
JOHN MILTON: \\ POET, PRIEST AND PROPHET
}




\section{By the same author \\ IMAGINATION IN COLERIDGE \\ THE ROMANTIC IMAGINATION: A CASEBOOK (editor)}




\title{
JOHN MILTON: POET, PRIEST AND PROPHET
}

A Study of Divine Vocation in Milton's Poetry and Prose

\author{
JOHN SPENCER HILL
}

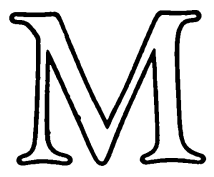




\title{
(C) John Spencer Hill 1979
}

Softcover reprint of the hardcover ist edition 1979

All rights reserved. No part of this publication may be reproduced or transmitted, in any form or by any means, without permission

First published 1979 by THE MACMILLAN PRESS LTD

London and Basingstoke Associated companies in Delhi Dublin Hong Kong Johannesburg Lagos Melbourne New York Singapore Tokyo

\section{British Library Cataloguing in Publication Data}

\author{
Hill, John Spencer \\ John Milton: poet, priest and prophet \\ I. Milton, John-Criticism and interpretation \\ I. Title \\ $82 \mathrm{I}^{\prime} \cdot 4$ \\ $\mathrm{PR}_{3588}$ \\ ISBN 978-1-349-03797-1 ISBN 978-1-349-03795-7 (eBook) \\ DOI 10.1007/978-1-349-03795-7
}

This book is sold subject to the standard conditions of the Net Book Agreement 
for

Christopher, Scott, and Katherine 


\section{Contents}

Preface $\quad$ ix

Abbreviations $\quad$ xiii

Introduction I

I Ministerial Vocation, 1625-40 27

2 Poetic Vocation, $1628-4^{2}$

3 Prophetic Vocation, $164^{1-6 o} \quad 77$

4 Paradise Lost $\quad$ I 5

5 Samson Agonistes

6 Paradise Regained $\quad 175$

Appendix

Milton Agonistes: The Date of Samson Agonistes $\quad 195$

Notes $\quad 205$

$\begin{array}{ll}\text { Index } & 229\end{array}$ 


\section{Preface}

This book began, now nearly a decade ago, as a doctoral dissertation at the University of Toronto. Believing that Milton's sense of divine calling was central to an understanding of much that he wrote, I set out to explore the growth of his vocational awareness and to demonstrate, if I could, how this conviction of special election might provide a conceptual framework for his entire literary production and a background against which to set his several careers as poet, 'priest', prophet and pamphleteer. The more familiar I became with his works, the more clear it seemed to me that divine vocation was a unifying theme throughout, although its emphasis changes and it acquires a spiritual and psychological complexity in the later works that is absent in the early material. I was struck by the fact that the early poetry up to and including $L y c i d a s$, despite its technical virtuosity and apparent assurance of tone, was tentative and essentially experimental, for Milton was engaged both in defining his role as poet-priest and in practising flight on his fledgling Pegasus. I sensed, too, that the truly decisive events later in his life were less immediately personal than national, less to be associated with his marriage failure and blindness than with his commitment to what he saw as England's divinely ordained destiny and the (consequently) traumatic experience of the Restoration in 1660 . From the early I 64 os, when he entered the controversy over episcopacy, Milton believed that his private calling was inextricably linked with and subservient to the national mission, and he came progressively to identify himself within the tradition of Old Testament prophecy. Now, for someone who had served for twenty years as the spokesman of national calling and had expended his divinely entrusted talents in the defence of theocratic republicanism, the Restoration made vocational reassessment inevitable; and this reassessment is reflected, I was convinced, in the poems that Milton published in 1667 and $167 \mathrm{r}$. A concern with vocation is omnipresent in the last three poems, and I felt certain that in some 
way the protagonists in these works-all of whom undergo vocational trials - provided Milton with correlatives for his own experience and enabled him, especially in the cases of Samson and the postlapsarian Adam, to achieve emotional calm and vocational redefinition as he traced in their spiritual growth his own gradual return to divine favour, rising phoenix-like from the smouldering ashes of the Puritan experiment.

Although my view of Milton's career and the place of divine vocation in his works remains substantially unaltered, the final product bears little resemblance in many ways to the original dissertation. While much of the material which appeared in the thesis reappears here, it has been considerably reworked and reorganised. Further reading has often enabled me to sharpen and extend the argument; and, at the same time, I have benefited greatly from the energies of Milton's critics, whose writings over the past ten years have deepened my appreciation of his achievement. I regret that Christopher Hill's Milton and the English Revolution (Faber, 1977) reached me too late to be taken into consideration; it is, I think, an important study, and a knowledge of it would have enabled me to exclude some of the historical material which perhaps makes my third chapter seem now somewhat too digressive.

Like everyone who writes on Milton I am indebted to the Miltonists whose insights form the foundation and much of the superstructure of my own approach. As an alumnus of the University of Toronto, it is, I suppose, inevitable that two such critics should be A. S. P. Woodhouse and Arthur E. Barker; but I owe a great deal, too, to such readers as E. M. W. Tillyard, Joseph H. Summers, Barbara K. Lewalski, Stanley E. Fish, Michael Fixler and others whose names appear in the notes at the end of this volume. Still other debts are of a more immediately personal nature. Professor W. J. Barnes of Queen's University (Canada) prompted my initial interest in Milton and helped to focus my early speculations about the role of vocation in the last poems. Professor H. R. MacCallum of the University of Toronto supervised the project as it took shape in the form of a dissertation; his deep understanding of Milton and his benevolent criticism of my work have saved me, both then and since, from innumerable errors of fact and judgement. I am grateful also to several friends and colleagues at the University of Western Australia who graciously set aside their own work to read the typescript at various 
stages of its development and to offer their suggestions: $\mathrm{Mr} \mathrm{D}$. A. Ormerod, Dr T. H. Gibbons and Dr C. J. Wortham. Special thanks are due to Dr Richard D. Jordan of the University of Melbourne, a friend and fellow Miltonist, who read through much of the final typescript with minute attention; his advice, although I have not always followed it, has been invaluable. My greatest debt, however, is to my family. My wife has experienced the writing of this book along with me and it could never have been completed without her constant sympathy and support; and our children, to whom the work is dedicated, have yielded precedence to Milton with a patience and understanding at which I can only marvel.

Early versions of portions of this book have already appeared in print. Chapters $I$ and 2 are based on my paper 'Poet-Priest: Vocational Tension in Milton's Early Development' which was published in Milton Studies, ed. James D. Simmonds, VIII (1975), 4I-69. Similarly, Chapter 5 is based on an article entitled 'Vocation and Spiritual Renovation in Samson Agonistes' which appeared in Milton Studies, II (1970), 149-74. Finally, I wish to thank the Yale University Press for permission to quote from Complete Prose Works of John Milton, general editor Don M. Wolfe (1953-*), and also Longmans, Green and Co Ltd for permission to quote from The Poems of John Milton, edited by John Carey and Alastair Fowler (1968). For the sonnets, however, I have used Milton's Sonnets, ed. E. A. J. Honigmann (London: Macmillan, I966).

\section{Perth, Australia}

28 April 1978 


\section{Abbreviations}

CV A Varionum Commentary on the Poems of John Milton. Merritt Y. Hughes, general editor. Projected in 5 vols (New York and London, 1970-*).

CW The Works of John Milton. F. A. Patterson, general editor. I 8 vols, plus 2 vols Index (New York, I 93 I-8).

$D B \quad$ Dictionary of the Bible. James Hastings, editor. Revised edition (New York, 1963).

$D D C$ Milton, De Doctrina Christiana.

ELH A Journal of English Literary History.

ES English Studies.

JEGP Joumal of English and Germanic Philology.

LM David Masson. The Life of John Milton. 6 vols, plus Index (first published, I880; reprinted, New York, I 965).

MB William Riley Parker. Milton: A Biography. 2 vols (Oxford, 1968 ).

MLN Modern Language Notes.

MLQ Modern Language Quarterly.

MLR Modern Language Review.

$M Q \quad$ Milton Quarterly.

ODCC The Oxford Dictionary of the Christian Church. F. L. Cross and $E$. A. Livingstone, editors. Second edition (London, New York and Toronto, 1974).

OED Oxford English Dictionary.

PL Milton, Paradise Lost.

PM The Poems of John Milton. John Carey and Alastair Fowler, editors (London and Harlow, 1968).

PMLA Publications of the Modern Language Association.

$P Q \quad$ Philological Quarterly.

$P R \quad$ Milton, Paradise Regained.

RES Review of English Studies.

$S A \quad$ Milton, Samson Agonistes.

SEL Studies in English Literature. 
xiv

John Milton: Poet, Priest and Prophet

SM The Student's Milton. F. A. Patterson, editor. Revised edition (New York, 1957).

SOED The Shorter Oxford English Dictionary. Third edition, revised (Oxford, I 975).

$S P \quad$ Studies in Philology.

TLS The Times Literary Supplement.

UTQ University of Toronto Quarterly.

YP Complete Prose Works of John Milton. Don M. Wolfe, general editor. Projected in 8 vols (New Haven and London, $1953^{-*}$ ). 